\title{
NA FRONTEIRA ENTRE O BEM E O MAL: ética profissional e moral religiosa entre policiais militares evangélicos cariocas
}

\author{
Elizabete Ribeiro Alberną*
}

\begin{abstract}
Este artigo analisa alguns paradoxos vivenciados por policiais militares evangélicos - membros ativos de congregações instaladas nos batalhões da Polícia Militar do Estado do Rio de Janeiro (PMERJ) - na busca por diálogo entre a sua fé, as prerrogativas de sua missão e os valores que informam a prática policial dominante. O estudo apóia-se no conceito de "técnicas de neutralização" de Sykes e Matza (1996), bem como na tipologia de Muir Jr. (1977) sobre as respostas policiais dos chamados "paradoxos da coerção". A análise mostra que a retórica maniqueísta da "batalha espiritual" é transposta para o ambiente policial militar e apropriada vigorosamente pela experiência da coerção. Esse resultado parece informar a construção de padrões éticos evangélicos de atuação policial, em que os conflitos cotidianos são encaminhados como expressões visíveis da influência nefasta do demônio, responsável pelo crime, pela devassidão e por toda sorte de comportamentos socialmente reprováveis.

PALAVRAS-CHAVE: polícia militar, cultura policial, evangélicos, batalha espiritual, discricionariedade policial.
\end{abstract}

\section{INTRODUÇÃO}

O processo civilizador submeteu o monopólio do uso legítimo da violência ao Estado, confiando-o a um grupo altamente exclusivo de indivíduos, responsáveis por resguardá-lo. Estes a quem a sociedade e o Estado outorgam o direito de coibir as formas de violência não-autorizadas - se necessário, com o uso da própria violência - tornam-se seres socialmente ambíguos, vítimas e algozes do poder de que foram investidos. No exercício desses atributos poderosos, submetem-se a riscos constantes que podem levá-los a se tornarem pessoas intelectualmente cínicas e moralmente degeneradas. Sua missão é eminentemente política: operar, nas fronteiras da legalidade, uma determinada ordem social; negociar seus princípios formais e as realidades sempre imperativas da vida social (Elias, 1994; Weber, 2000).

* Mestre em Antropologia Social. Assessora Técnica de Gabinete da Secretaria de Estado dos Negócios da Segurança Pública de São Paulo.

Rua Líbero Badaró, 39, $12^{\circ}$ Andar. Centro. São Paulo-SP. Cep: 01009-000. betealbernaz@yahoo.com.br
Dentre as categorias profissionais autorizadas a desempenhar esse papel, os policiais bem como as forças armadas, ${ }^{1}$ muito embora com enfoques bastante distintos - dispõem do recurso ao símbolo último do poder coercitivo para executar sua missão: a arma. No exercício de seu ofício poderoso, esses agentes enfrentam ameaças constantes, em que frações de segundos podem encenar escolhas - dramáticas e nem sempre conciliáveis - entre vida e morte. Entretanto, diferentemente de seus opositores, os policiais encontram-se constrangidos em suas ações por leis, regulamentos, expectativas sociais, princípios éticos e valores. "Poderosos, mas não absolutamente poderosos" (Muir Jr, 1979, p.4), vivem intensamente os paradoxos do exercício do poder coercitivo, para os quais precisam produzir respostas eficazes, mas que sejam moral e legalmente respaldadas.

${ }^{1}$ No Brasil, a história das polícias militares esteve fortemente vinculada às forças armadas, com as quais compartilhavam atribuições acerca da segurança interna e nacional. Mesmo depois da retomada de suas funções civis, suspensas por quase um século, suas competências continuaram confusas, uma esquizofrenia que ainda marca o exercício da autoridade policial militar. Para um maior aprofundamento da discussão, ver Muniz (2001).

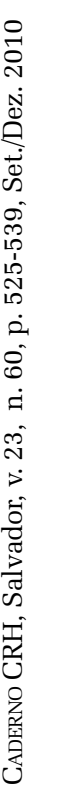


É bastante comum certa incompreensão não só da população em geral, mas dos próprios policiais - acerca da prerrogativa do uso da força, do exercício da violência autorizada pelo Estado. Em torno dessa incompreensão, orbitam alguns perigos. O primeiro deles é a consolidação de falsas oposições entre a ação policial e a defesa dos Direitos Humanos. O segundo, e talvez mais temeroso, ocorre quando esse senso comum extrapola a opinião pública e contamina as organizações policiais. Ao tentar excluir a prerrogativa de uso da força de suas interações cotidianas com os cidadãos, os policiais tendem a restringila a situações em que se veem claramente ameaçados, limitando seu poder de oferecer respostas adequadas ao amplo espectro de solicitações da população (Muniz; Proença Jr.; Diniz, 1999). ${ }^{2}$

Esta suposta disjunção - que afasta, perigosamente, o exercício autorizado da violência da garantia de direitos -, além de reduzir o uso da força a sua forma letal (o uso da arma), tende a fornecer justificativas para uma série de atitudes não-profissionais, fundamentadas na suposta incoerência entre a força e qualquer concepção humana de bondade e justiça. Além disso, a pressão por resultados (o clamor público, as prioridades de governo, as medidas de produtividade etc.) tende a acentuar essas percepções equivocadas, justificando abusos e (ou) atitudes omissas por parte dos policiais frente à constatação de lacunas no funcionamento do sistema: a lentidão da justiça; a falta de equipamentos e treinamento; baixos salários; a perseguição da imprensa etc.

Com essa última afirmação, entretanto, não pretendo negar a existência de tais problemas e seus impactos sobre a ação policial. Retomo aqui as contribuições de Sykes e Matza (1996) acerca das chamadas "técnicas de neutralização" da culpabilidade, em que os sujeitos acionam discursos apreendidos culturalmente para justificar suas ações frente às normas e padrões sociais

${ }^{2}$ A competência específica da polícia, segundo Bittner (2003), está diretamente relacionada à prerrogativa de uso da força, a sua capacidade de ação decisiva no exercício da autoridade para subjugar qualquer oposição ao lidar com um amplo espectro de situações emergenciais, que não se restringem às ações de controle da criminalidade. dominantes. O policial que justifica a corrupção pelos baixos salários, por exemplo, aciona uma explicação socialmente legítima (a indignidade de seus proventos) para respaldar seu comportamento desviante. A utilização desse argumento como "técnica de neutralização", entretanto, não torna menos verdadeira a penúria salarial em que vivem os policiais.

No presente artigo, pretendo analisar os relatos fornecidos por policiais militares evangélicos - membros ativos de congregações interdenominacionais instaladas nos batalhões da Polícia Militar do Estado do Rio de Janeiro (PMERJ) - acerca de seus esforços e dificuldades na busca por alternativas de diálogo entre os princípios de sua fé, as prerrogativas de sua missão e os valores que informam a prática policial dominante. Para trabalhar teoricamente as experiências e depoimentos coletados durante o trabalho de campo, lançarei mão das análises de Sykes e Matza (1996) sobre as chamadas "técnicas de neutralização", bem como da tipologia de William Ker Muir Jr. (1977) sobre as formas profissionais e não-profissionais de respostas policiais aos chamados "paradoxos da coerção".

Expostos aos dilemas e ambiguidades da profissão policial - como "seres poderosos, mas não totalmente poderosos", autorizados a reprimir as formais ilegais de violência e proteger uma determinada ordem social, se preciso com o uso da própria violência -, os policiais evangélicos elaboram justificativas complexas para suas escolhas, buscando afirmar sua validade temporal (frente à "lei dos homens") e atemporal (frente à "lei de Deus"). Tomadas como "técnicas de neutralização" (Sykes; Matza, 1996), tais justificativas temporais e atemporais, da "lei dos homens" e da "lei de Deus" facultam acesso aos processos de aprendizado subculturais que as informam (a relação com os colegas, o engajamento em determinados tipos de policiamento etc.), bem como aos valores sociais mais amplos a que se referem (o valor da vida humana, concepções de honra, coragem, bem e mal). Segundo Muir Jr (1977), a elaboração equivocada dessas tensões no exercício da coerção 
pode resultar em um amplo espectro de "respostas não-profissionais", que vão desde a negação do recurso à força (omissão, evitação etc.) à barganha da autoridade policial (corrupção, privatização da segurança etc.), até à perda de referenciais éticos e à aquisição de uma visão cínica dos dramas humanos ( expressa no abuso de autoridade, violência policial etc.).

Analisando as trajetórias evangélicas a partir da tipologia de Muir Jr (1977) e da contribuição de Sykes e Matza (1996), espero facultar ao leitor três registros possíveis de minha experiência de estudo da PMERJ. Uma primeira leitura se refere aos impactos da introdução de uma ética dualista exclusivista - que estabelece uma divisão clara e não-mediada entre o "bem e o mal", "o certo e o errado" - no ambiente cultural da organização. Ao identificar as aproximações e os distanciamentos entre o ethos policial e a moral cristã-evangélica, buscarei, em seguida, delinear as estratégias e justificativas de que meus interlocutores lançam mão para responder a dois importantes focos de tensão da experiência evangélica: o uso da arma e o envolvimento com atividades de guarnição. E, por fim, espero produzir um conjunto de inferências mais amplas acerca dos limites e possibilidades institucionais na consolidação de atitudes profissionais, a partir das soluções encontradas pelos policiais na busca por alternativas moralmente integradas para resolver o dilema de produzir fins justos por meio da força.

\section{TRABALHO DE CAMPO}

Os dados aqui apresentados foram coletados ao longo dos cerca de oito meses de trabalho de campo intensivo na Polícia Militar do Estado do Rio de Janeiro (PMERJ). A pesquisa completa, entretanto, teve a duração de dez meses e envolveu duas etapas distintas. Na primeira etapa, entre março e junho de 2007, realizei 21 entrevistas com evangélicos de profissões diversas, buscando estabelecer diálogos entre a sua fé e seu desempenho funcional. Além disso, foram realizadas visitas semanais a cinco denominações: Igreja Universal do Reino de Deus, Assembleia de Deus, Igreja Batista, Igreja Adventista do Sétimo Dia e Nova Vida. Durante esse período, consegui reunir um material bastante interessante a partir da observação dos cultos, acumulando um acervo significativo de publicações, folhetos e outros escritos distribuídos durante as pregações.

A segunda etapa da pesquisa de campo, cujos resultados serão analisados mais detalhadamenteno presente artigo, foi levada a cabo entre os meses de julho e dezembro de 2007. Nesse período, pude realizar um total de 37 entrevistas: $20 \mathrm{com}$ policiais militares evangélicos, sete com policiais não-evangélicos e dez com ex-policiais militares, todos evangélicos, nas dependências do Presídio Ary Franco.

As entrevistas, observações de campo e coleta de materiais foram realizadas nas seguintes unidades policiais: BOPE (Laranjeiras), $5^{\circ} \mathrm{BPM}$ (Saúde), 13ํㅡㄹ (Centro), 14 ${ }^{\circ} \mathrm{BPM}$ (Bangu), $24^{\circ} \mathrm{BPM}$ (Queimados), ${ }^{\circ} \mathrm{BPM}$ (Botafogo), Hospital Central da Polícia Militar (HCPM-Estácio) e Batalhão Especial Prisional (BEP-Benfica).

Sobre a amostragem de policiais militares, grande parte das entrevistas e observações de campo foi realizada entre os praças (soldados, cabos e sargentos), não só porque são maioria na corporação (cerca de $92 \%$ do efetivo total), mas também em razão de seu maior envolvimento no movimento evangélico organizado. ${ }^{3}$ Encontrei dificuldades também em acessar policiais diretamente envolvidos com atividades de policiamento ostensivo, o que fez com que a

${ }^{3}$ Não existem dados oficiais que corroborem essa percepção; entretanto, a partir de minha inserção no campo, o movimento evangélico da PMERJ me pareceu um movimento de praças, mais especificamente de sargentos. Tomento de praças, mais especificamente de sargentos. Tonão tenho notícias de nenhum oficial como dirigente. Tendo em vista que o oficialato representa apenas $8 \%$ de todo o efetivo da PMERJ, o número de oficiais evangélicos tende '? a ser ainda menor, o que diminui também as chances de encontrá-los exercendo esse tipo de função. Além disso, o cargo de dirigente de congregação aproxima-se mais do tipo de função de chefia exercida por sargentos, o que explicaria o fato de a grande maioria das congregações na PMERJ serem dirigidas por representantes desse segmento hierárquico. Dentre os praças, a graduação de sargento é também aquela com maiores possibilidades para o desempenho de funções administrativas internas, situação

章


maioria das entrevistas fosse realizada com policiais em setores administrativos. Muitos possuíam experiência de rua - algumas vezes, uma rica e vasta experiência -, mas trabalhavam internos na época da pesquisa. Essa limitação levou-me a buscar meios alternativos para recolher depoimentos junto aos policiais envolvidos em atividades ostensivas, in loco, durante os turnos de serviço.

Como minha pesquisa se restringia ao ambiente interno das unidades, decidi treinar um experiente sargento evangélico como meu assistente de campo, em razão de sua intimidade com o tema e da facilidade de trânsito entre os colegas nas ruas. O Sargento Carlos Fernandes ${ }^{4}$ já colaborava ativamente com diversas pesquisas e era instrutor do Curso de Aprimoramento da Prática Policial Cidadã desde 2002, ano em que iniciei como estagiária de monitoramento do projeto, desenvolvido pelo então Programa de Ações em Segurança Pública da ONG "Viva Rio”. Quando decidi trabalhar com o tema do movimento evangélico na PMERJ, em 2006, Fernandes foi meu primeiro entrevistado e me auxiliou na organização inicial de ideias para a pesquisa. Para que pudesse realizar um conjunto de cinco entrevistas (além das 37 realizadas por mim), conversamos longamente sobre meus interesses teóricos, problemas práticos, público-alvo, bem como sobre a metodologia e o roteiro de perguntas. Antes de engajar-se totalmente na pesquisa, Fernandes fez uma entrevista-piloto, cujos pontos fortes e fracos foram trabalhados entre nós. Seu ótimo desempenho como entrevistador e o olhar apurado

mais ajustada à demanda de trabalho de um dirigente. Depois de mais de 15 anos de serviço, muitos sargentos adquirem mazelas de saúde ou acabam buscando um serviço mais tranquilo para encerrar a sua carreira; outros assumem a chefia ou a assistência de alguma seção, dentro do perfil funcional previsto para o segmento na estrutura hierárquica da corporação (Albernaz, 2009, p.149).

4 "Nascido em lar evangélico”, em 2006, na época de nossa primeira entrevista, Fernandes tinha 48 anos de idade e 24 anos de serviço, com uma vasta experiência no policiamento ostensivo. Em 1996 sofreu um acidente, sendo realocado em setores administrativos de seu batalhão. "Afastou-se do evangelho" pouco antes de ingressar na PMERJ e retornou aos 40 anos, cerca de dois anos depois do acidente que o levou a se afastar da "rua". Carlos Fernandes é um cristão altamente engajado, pastor da Igreja Cruzada Mundial de Missões e responsável pela congregação evangélica do $2^{\circ} \mathrm{BPM}$, em Botafogo, bairro da zona sul da cidade do Rio de Janeiro. para as questões do campo fizeram dele um colaborador importantíssimo, com quem eu discutia muitos dos resultados da pesquisa. Graças a ele, pude captar mais das percepções dos policiais evangélicos que trabalhavam nas ruas da cidade do Rio de Janeiro, aos quais tinha acesso limitado em razão das especificidades do trabalho de campo. Suas entrevistas foram analisadas separadamente na dissertação e, como veremos a seguir, facultaram-me acesso a categorias importantes do universo das ruas.

\section{OS "POLÍTICOS DE ESQUINA"}

A partir do final dos anos 60, a literatura sociológica americana, impulsionada pelos desdobramentos políticos dos movimentos de defesa dos direitos civis, dedicou-se a investigar empiricamente a questão da discricionariedade policial e da eficácia dos mecanismos de controle e responsabilização sobre as ocorrências de desvios de conduta. As pesquisas levavam em consideração dois planos de análise, avaliados segundo a sua adequação às expectativas da sociedade e aos parâmetros de legalidade vigentes: os procedimentos adotados pela força policial e os comportamentos individuais de seus membros em situações reais do policiamento. A principal preocupação de gestores públicos e pesquisadores era medir o impacto das reformas institucionais (criação de estruturas, sistemas, emissão de regramentos e procedimentos) sobre as práticas policiais concretas, transformando as prioridades e estratégias levadas a cabo nas interações cotidianas com as comunidades. ${ }^{5}$

Diversos estudos se propuseram a desenvolver tipologias detalhadas das diferentes ori-

${ }^{5}$ Duas linhas teóricas dominaram o cenário acadêmico da época: os interacionistas, cujas análises centravam-se nas relações sociais e na existência de uma "cultura policial"; e os estruturalistas, que afirmavam a necessidade de uma análise profunda do lugar estrutural do exercício do poder discricionário na organização legal do Estado. Embora existissem essas ênfases teóricas diferenciadas, muitas pesquisas transitavam entre esses dois níveis de análise, micro e macrossociológicos. Uma linhagem importante desses estudos sociológicos atribuiu especial atenção ao 
entações e estilos de ação policial. Um deles, em especial, ateve-se ao caráter eminentemente político do policiamento, atribuindo a cada policial um papel fundamental como "políticos de esquina”, mediadores microscópicos das relações de poder dentro da sociedade. "Streetcorner Politicians" (1977), do cientista político William Ker Muir Jr., é uma obra de referência obrigatória na sociologia das instituições policiais norteamericanas. Tributário das técnicas de observação participante da chamada "Escola de Chicago” - o título de seu livro remete ao clássico trabalho de William Foote Whyte, "Street Corner Society: The Social Structure of an Italian Slum" $(1943)^{6}$-, Muir imergiu no cotidiano profissional de 28 jovens policiais americanos, todos envolvidos em atividades de patrulha, pertencentes ao Departamento Policial da Cidade de Lacônia, no início da década de 70.

Em sua pesquisa de campo, Muir dedicouse à observação das habilidades e atributos de um "bom policial”, analisando as atitudes de seus interlocutores em relação aos dilemas e paradoxos do exercício autorizado do poder coercitivo.

What is a good policeman, and what does he think and do differently from a bad one? Does police work corrupt, or does it expand a policeman's horizons and magnify his soul? Can anything be done to avert the potential for his moral breakdown?? (Muir, 1979, p.3).

relacionamento entre as regras formais, leis e procedimentos, e as regras subculturais, que são as diretrizes da conduta policial. A despeito do que possa parecer a um observador externo desavisado, a cultura da polícia não é monolítica. Sua diversidade é proporcional às possibilidades de experiências distintas associadas a posições estruturais específicas, à exposição a diferentes padrões de problemas e a referências trazidas de sua biografia e histórias anteriores. Para esses autores, a análise das chamadas "subculturas policiais" seria a chave para a compreensão da discricionariedade policial (Reiner, 2004a, p.246-248).

6 “Originalmente publicado em 1943, o texto é não apenas atual pela temática que aborda - a juventude, a organização social das gangs e dos bairros pobres -, mas também constitui um livro fundamental para aqueles que fazem trabalho de campo nas cidades, realizando o que os norte-americanos denominam anthropology at home. É também de grande importância para os sociólogos urbanos que cada dia aderem mais aos métodos qualitativos e aos estudos de caso e se interessam pelo tema das redes sociais, da juventude, da política local e da territorialização da pobreza" (Valladares, 2007).

7 “O que é um bom policial, e o que ele pensa e faz diferentemente de um mau policial? O trabalho policial corrompe, ou ele expande os horizontes do policial e magnífica a sua alma? Algo pode ser feito para evitar seu potencial colapso moral?".
Para desenvolver sua discussão, o autor se vale de dois pressupostos fundamentais: o efeito corruptor do poder e a natureza moral dos seres humanos. Segundo afirma, dentre as técnicas de exercício do poder disponíveis - coerção, reciprocidade e exortação -, a coerção parece exigir qualidades humanas e atributos individuais incompatíveis com qualquer noção civilizada de bem e de bondade (Muir, 1979, p.48).

De modo a apreciar a natureza da coerção de forma mais profunda, dando conta de suas formas autorizadas e não-autorizadas, Muir (1979) desenvolveu um modelo simplificado das relações de coerção, chamado por ele de "extortionate transaction" ("transação extorsiva”). Esse modelo - construído a partir de circunstâncias típicas da rotina de patrulhamento - permitiria visualizar as armadilhas implicadas no exercício da coerção, encarnadas no que o autor denominou "paradoxos do poder coercitivo":

1. The paradox of dispossession: the less one has, the less one has to lose; 2 . The paradox of detachment: the less the victim cares about preserving something, the less the victimizer cares about taking it hostage; 3 . The paradox of face: the nastier one's reputation, the less nasty one has to be; 4 . The paradox of irrationality: the more delirious the threatener, the more serious the threat, the more delirious the victim, the less serious the threat (p. 44). ${ }^{8}$

A coerção exerce um papel crucial na construção da compreensão policial do mundo, de sua visão acerca da natureza humana e do papel da sociedade. Como criaturas morais, os policiais são constantemente assombrados por dilemas inerentes ao exercício da violência autorizada e ao fato de serem poderosos, mas não absolutamente poderosos para reagir às situações em que se veem enredados. Segundo Muir (1979), à medida que encontram soluções efica-

8 "1. O paradoxo da desapropriacão: quanto menos se tem, menos se tem para perder; 2 . O paradoxo da indiferença: quanto menos a vítima se importa em preservar alguma coisa, menos o agressor se importa em tomá-la; 3 . O paradoxo da reputação: quanto pior a reputação, menor a probabilidade de se ter de provar sua potencial maldade; 4 . O paradoxo da irracionalidade: quanto mais delirante o agente da extorsão, mais séria é a ameaça; quanto mais delirante a vítima, menos séria é a ameaça”. 
zes diante dessa assimetria de meios para lidar com os paradoxos da coerção, os policiais passam a reconhecer o uso do poder coercitivo como estratégia legítima, reconciliando seus padrões de moralidade e as prerrogativas associadas à sua atividade profissional (p.224).

Para analisar o desenvolvimento dos atributos constitutivos de um "bom policial", Muir recorre à sociologia de Max Weber, em seu texto clássico "A Política como Vocação", ${ }^{9}$ em que o autor analisa os processos históricos e sociológicos que possibilitaram o surgimento da figura do "político profissional". Em sua leitura de Weber, Muir afirma que - assim como o "político profissional" - o "bom policial" deve desenvolver duas virtudes para atingir um padrão adequado de respostas aos paradoxos da coerção: intelectualmente, deve desenvolver uma compreensão trágica compartilhada do sofrimento e da natureza humanos, que lhe permita sustentar níveis aceitáveis de empatia por aqueles a quem deve coibir; moralmente, deve resolver a contradição de obter fins justos por meios coercivos, permitindo que o seu envolvimento com a violência seja eivado de princípios (Muir Jr, 1979, p.50-51). ${ }^{10}$

Para a tipologia de Muir, os policiais, como resultado de suas respostas aos "paradoxos do poder coercitivo", podem desenvolver atitudes morais "integradas" ou "conflituosas". Uma visão moralmente integrada torna a coerção consistente com os códigos que regulam e dão valor à conduta de vida do policial, dissipando sentimentos de culpa e conflituosidade. A ética da violência com princípios, entretanto, não é suficiente. Uma moral integrada pode ser atingida

${ }^{9}$ Conferência proferida em 1919, na Universidade de Munique, pouco tempo antes de falecer.

${ }^{10}$ Derivado de seu modelo profissional, Muir definiu três tipos de atitudes não-profissionais: o "fujão” (avoider), de perspectiva cínica e moral conflituosa, se esquiva das obrigações e evita as circunstâncias em que deve usar a coerção; o “alternante” (reciprocator), de perspectiva trágica e moral conflituosa, hesita em usar o poder coercitivo, mesmo quando é apropriado; o "sancionador" (enforcer), com perspectiva cínica e moral integrada, age no calor do conflito e sem compreender a necessidade de controle. Para a tradução dos perfis não-profissionais de respostas os dilemas da coerção, foi utilizada uma sugestão oferecida por Reiner (2004a, p.154). não pela reconciliação, mas pela rejeição das preocupações éticas da civilização, da adoção de uma atitude intelectualmente cínica. Para Muir, três fatores seriam cruciais no desenvolvimento das qualidades morais e intelectuais do "bom policial": o cultivo da eloquência, que habilita o policial a construir alternativas ao uso da força coerciva, transmitir esses conhecimentos e elaborar emocionalmente as suas vivências; a relação com os colegas, especialmente com seus supervisores; e a liderança de seu chefe, no que se refere à definição de diretrizes institucionais e na condução de processos de reforma.

\section{NA FRONTEIRA ENTRE O BEM E O MAL}

É bastante difundida, nos meios policiais, a concepção de que sua missão envolve o contato diário com "o que existe de pior na sociedade", com o que há de mais obscuro na alma humana. Muitos concebem o lugar de polícia como um lugar de fronteira entre a legalidade e a ilegalidade, entre o bem e o mal, a "tênue linha azul" que salvaguarda a ordem social da barbárie (Reiner, 2004a, p.137).

No decorrer dessa pesquisa, a religião apareceu como um tipo de instrumento poderoso de negociação das realidades conflitivas e frustrações da experiência policial militar, atribuindo sentido às inconsistências vivenciadas pelos sujeitos e oferecendo conforto ou mesmo suporte emocional. No caso dos policiais militares evangélicos, a experiência da conversão também faculta um novo entendimento para a situação da segurança pública no Rio de Janeiro, que se fundamenta na ideia de "batalha espiritual". ${ }^{11}$ A violência, as disputas territoriais do tráfico de drogas, as milícias, a letalidade, a vitimização policial etc., seriam reflexos temporais da batalha celestial entre Deus e o diabo pelas almas humanas, que finalmente estaria chegando a seu termo. O tempo profético do juízo, previsto no livro do Apocalipse, é iminente, o que produziria a intensificação das estra${ }^{11}$ Para maiores informações ver Mariz (1999) . 
tégias ardilosas do demônio, empenhado em afastar o máximo de almas possível das graças de Deus antes de sua inevitável derrota.

Depois que eu aceitei Jesus, eu comecei a entender que aquela pessoa [o traficante] é um igual. E nós aprendemos que nossa luta não é contra carne nem contra sangue, mas contra Principados e Potestades. Potestades são poderes; Principados são principais, tá? Demônios! São Demônios. E nós brigamos muito com Demônios e eu passei a entender isso. Que aquele irmão que está me atacando ele não está me atacando porque ele quer me atacar. Ele está sendo induzido a fazer aquilo. O traficante, aquelas pessoas que estão à margem da lei, eu comecei a ver comecei a aprender, comecei a ser revelado pelo Espírito Santo que aquilo são potestades, são Demônios que atuam naquelas pessoas. Na falta de buscar Deus, a pessoa fica na indiferença, então, acaba sendo alvo fácil pras obras do Maligno; fica na indiferença, não busca Deus, não dá crédito na palavra de Deus, não obedece a Deus, vive no mundo do pecado, então, a pessoa acaba sendo usada, acaba sendo escrava do pecado, né? E cometendo várias coisas abomináveis aos olhos dos homens aí, os casos de violência que a gente vê hoje em dia, né? O Maligno atua na vida dele.

(Cabo evangélico, 33 anos, 8 anos de polícia, 5 anos de conversão).

O inesgotável potencial explicativo da retórica maniqueísta da "batalha espiritual" é transposto para o ambiente policial militar e apropriado de modo bastante vigoroso pela experiência da coerção. Em parte, isso se deve às concepções beligerantes de bem e mal que já circulam no ambiente institucional e no debate público sobre segurança (Sento-Sé, 1997; Zaluar, 1997). Em razão de sua viva compreensão dos dilemas do poder coercitivo, não é incomum que os policiais desenvolvam uma postura de desconfiança sistemática, sempre em busca do mal escamoteado pela aparente normalidade e respeitabilidade das pessoas. Trata-se de uma concepção de mal como potencial humano, inerente, cujo espectro recobriria desde a falha de caráter mais inofensiva, até o comportamento mais perverso. Essa compreensão cínica dos dramas humanos pode acentuar sentimentos de antagonismo, em que o policial se distancia perigosamente daqueles a quem deve coibir, situando-os em domínios ontologicamente diversos: o policial, como guardião das forças do bem, da ordem, da legalidade; e o "rebelde" (o bandido, o traficante etc.), que resiste à autoridade policial, como representante do mal, da desordem, do crime e da violência. ${ }^{12}$

O policial militar evangélico, ao desdobrar o confronto para o plano espiritual, acrescenta uma dimensão diferenciada na compreensão do fenômeno, em que seu opositor (o traficante, o bandido) aparece como mero "instrumento". O mal a ser combatido é o pecado, bem como a indiferença que torna os sujeitos suscetíveis aos "ardis do demônio". Diferente das concepções maniqueístas culturalmente aceitas como justificativas para neutralizar a culpabilidade dos policiais, a ideia de "batalha espiritual" cria dificuldades extras para a elaboração evangélica da experiência da letalidade: matar, nesse caso, significa privar não só o corpo da vida material, mas a alma da vida eterna. No tópico seguinte, tratarei de modo mais detalhado das técnicas retóricas de neutralização que permitem aos evangélicos elaborarem a experiência do uso da arma de forma moralmente integrada.

Para os policiais militares evangélicos, o imperativo de trilhar o caminho da salvação em um campo impregnado de maniqueísmos tende a submeter os sujeitos a um amplo espectro de tensões entre seus valores religiosos e condutas profissionais concretas. Evidentemente, nem tudo no cotidiano de um policial militar tensiona a experiência evangélica e vice-versa. Entretanto, existem aspectos desse universo sobre os quais se

12 "Gerada no âmbito do conturbado relacionamento entre a polícia e as camadas pobres urbanas cariocas, fortaleceuse no debate público sobre segurança uma concepção de mal como anomalia social, um lugar ocupado hoje majoritariamente pela figura do tráfico de drogas e da violência urbana em geral (Santo-Sé, 1997; Zaluar, 1997). Em um campo semântico altamente maniqueísta, "o traficante" encarnaria o poder nefasto e desagregador das forças do mal, que estabelecem o caos social; em oposição, encontrar-se-iam os policiais, representantes dos esforços do bem em restabelecer a ordem pública. Na prática, entretanto, sabe-se que essas dicotomias não se sustentam com clare$\mathrm{za}$, servindo apenas para polarizar discursos e atitudes em torno do tema. Analisando as políticas de segurança pública adotadas pela gestão estadual desde 1983, podese perceber que a demonização do crime tem sido utilizada como embasamento ideológico para uma série de violações perpetradas contra segmentos marginalizados da sociedade, como os moradores de favelas e periferias. As ações arbitrárias e violentas da polícia acabam sendo legitimadas pelo medo de uma sociedade que erigiu a segurança pública como um fim em si mesmo, independente dos meios e custos humanos." (Albernaz, 2009, p.189).

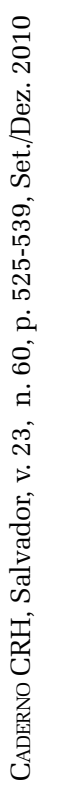


estruturam vastos campos de controvérsias entre evangélicos e não-evangélicos, na corporação. Ao expor os sujeitos a essas controvérsias, a partir das entrevistas, busquei explorar o intenso potencial criativo acionado pelas dimensões conflitivas de suas experiências. Para a análise proposta no presente artigo, escolhi ater-me a dois pontos de controvérsias: a suposta predileção dos policiais evangélicos por serviços administrativos e a aparente contradição entre o uso da arma de fogo e o mandamento bíblico "não matarás”.

\section{USO DA ARMA DE FOGO: a "legitima defesa" e o "não matarás"}

Um exemplo bastante paradigmático do potencial criativo das tensões entre a experiência religiosa e profissional dos policiais evangélicos é a polêmica sobre o uso da arma. Para o público em geral, parece irreconciliável o fato de um evangélico portar uma arma de fogo e, ao mesmo tempo, cumprir o mandamento sagrado de "não matarás". Entretanto, a situação traduz com bastante propriedade a condição dos policiais militares evangélicos na corporação, que precisam lidar com expectativas conflitantes em torno de seu comportamento como evangélicos e como policiais. Como pude identificar, são bastante comuns manifestações de incompreensão acerca das razões de um evangélico sentir-se atraído pela profissão policial; ou, ao contrário, que um policial venha a converter-se ao Evangelho. Para aqueles que nutrem uma imagem da Polícia Militar como uma instituição corrompida e violenta, a descrença quanto à existência de "verdadeiros cristãos" na corporação tende a se acentuar.

Se, junto ao público externo, o policial evangélico luta para desvincular-se da imagem de truculência associada à sua profissão, afirmando-se como cristão, internamente é incitado a demonstrar que pode exercer sua autoridade com energia, afirmando-se como policial militar. Muitos de seus colegas de farda teriam uma imagem do evangélico como um pacifista radical, que reluta em utilizar sua arma e evita expor-se a situações de conflito. Quando se deparam com um evangélico cujo comportamento não se enquadra nesse estereótipo, alguns chegam a colocar em dúvida sua seriedade como cristão. Por outro lado, quando o policial procura seguir muito à risca os fundamentos cristãos, pode passar a ser questionado em seu "profissionalismo", pois não estaria conseguindo separar sua religião das exigências de sua profissão.

Lidando com expectativas conflitantes sobre seu comportamento - dentro e fora da Polícia Militar-, os policiais evangélicos entrevistados parecem acostumados aos questionamentos sobre a suposta incoerência entre o exercício da autoridade policial, o uso da arma e os padrões de vida cristã. Sobre isso, desenvolvem uma argumentação muito interessante, que articula a figura jurídica da legítima defesa, personagens bíblicas e a ideia de outorga divina das autoridades terrenas. Com base nas Escrituras, os policiais militares evangélicos entrevistados, quando questionados sobre esse ponto, foram unânimes em invocar a passagem de Romanos (13:1-4) ${ }^{13}$ e a figura do Rei Davi, para demonstrar os precedentes bíblicos da autoridade policial, mesmo quando seu exercício coloca a necessidade de tirar a vidas.

A Bíblia fala, no livro de Romanos, capítulo 13, "Que as autoridades são constituídas por Deus". Entendeu? Então, não há autoridade que não seja constituída por Deus e a autoridade não traz em vão a espada. Mas o que é a espada? A correção. Então, a Bíblia fala que "Se Deus não guardar a cidade, em vão vigiam os seus sentinelas”. A cidade precisa de policiais? Precisa de autoridades? De segurança pública? Precisa, mas tem que estar em Deus em primeiro lugar. Eu acho que é por causa do tipo de serviço que é praticado, tem muita gente que não conhece a lei por falta de entendimento bíblico, e até mesmo do Código Penal, eles não leem e não sabem que o policial, tal como outro, pode prender em flagrante delito

\footnotetext{
3 “Toda a alma esteja sujeita às potestades superiores; porque não há potestade que não venha de Deus; e as potestades que há foram ordenadas por Deus. Por isso quem resiste à potestade resiste à ordenação de Deus; e os que resistem trarão sobre si mesmos a condenação. Porque os magistrados não são terror para as boas obras, mas para as más. Queres tu, pois, não temer a potestade? Faze o bem, e terás louvor dela. Porque ela é ministro de Deus para teu bem. Mas, se fizeres o mal, teme, pois não traz debalde a espada; porque é ministro de Deus, e vingador para castigar o que faz o mal." (Romanos, 13:1-4).
} 
e também qualquer pessoa pode se defender matando a outra na sua defesa, legítima defesa. Na bíblia tem várias ocorrências do Antigo Testamento de batalhas onde morreram muitas pessoas e todas eram servos do Senhor. [...] Nós, quando invadimos um morro, ou quando a gente investe contra um meliante qualquer, nós, além de estarmos em obediência ao próprio serviço em si, nós estamos defendendo a população que é um juramento que se faz quando se entra. [...] Nós não tínhamos esta violência, na hora do conflito, daquele caos todo, que a gente está vendo, que está na eminência... que a gente está vendo que o bandido vai aparecer e que você vai ter que eliminar ele. Naquela hora, passa na sua cabeça a mãe, o filho, irmão, entendeu? Pode ser um cristão que está afastado, que está naquele mundo e está na beira de sair e você vai tolher ele, porque ele vai aparecer ali na brecha e você vai ter que combater ele. Isso é muito difícil, foge ao controle e a obrigação vem em primeiro lugar, mas se você não atirar nele ele vai atirar em você. Aí você passa a pensar nos filhos, na mãe, na parentela toda. Então, você acaba compensando esta frustração que você sente na hora, esse receio, essa sensação estranha, compensando com o que se não for ele vai ser você. Só não pode começar a gostar disso. Você se torna disponível para tirar a vida dos outros quando você, na sua folga ou no seu serviço, tem este tipo de pensamento, porque você, antes de qualquer coisa, tem que imaginar que tem soluçã̃o para aquela crise ali.

(Cabo evangélico, 34 anos de idade, 10 anos de polícia, 6 anos de conversão).

Como agente da autoridade - temporal e atemporal -, o policial militar evangélico, ao revidar uma injusta agressão, estaria em obediência ao preceito legal e ao fundamento bíblico. Para preservar a sua vida ou a de terceiros, esgotadas todas as alternativas de uso da força disponíveis, o policial está autorizado a utilizar a sua arma para atentar contra a vida de seu agressor em legítima defesa. Entretanto, o fato de estar respaldado não torna as circunstâncias de confronto armado menos tensas e eticamente conflituosas para o evangélico - ou para qualquer policial que guarde, minimamente, alguma empatia pelos dramas humanos e sofrimentos alheios.

Evangélicos ou não, os policiais militares tendem a construir justificativas para reduzir as ambiguidades morais envolvidas na letalidade: a vida é um valor sagrado para a sociedade; tirar a vida de uma pessoa é um ato socialmente reprovável; ao policial é delegado o poder de tirar vidas na defesa da sociedade. Uma estratégia bastante comum de neutralização da culpabili- dade, no sentido atribuído por Sykes e Matza (1996), é a caracterização da situação de "vida e morte". Mesmo quando legal e tecnicamente amparada, a ação policial que resulta em morte - uma das vivências mais extremas da atividade policial - tende a acionar justificações que unifiquem moralmente as ambiguidades desse resultado dramático da atividade coerciva. "Só não pode começar a gostar disso", alerta o entrevistado, reconhecendo a possibilidade de que as técnicas de neutralização contidas na retórica da situação de "vida e morte" podem ter como efeito a banalização do valor da vida humana.

Submetido a uma situação de vida ou morte, o policial militar evangélico entende que, ao tirar uma vida, ele está privando uma alma da salvação e entregando-a nas mãos de satanás. Como evangélico, ele sabe que sua principal batalha é espiritual e que seus oponentes são pessoas que se deixaram usar pelas forças do mal. Como policial, ele sabe que essa constatação não deve impedi-lo de tomar as medidas cabíveis, dentro dos limites da lei e da técnica. Apesar disso, é bastante comum que policiais militares evangélicos evitem se envolver com determinadas atividades operacionais, em que a possibilidade de uma ação com resultado fatal é mais pronunciada. A morte, nesse sentido, representa o fracasso da missão evangelizadora do povo cristão, que não conseguiu trazer aquela alma para Deus em tempo - mas também a falência do Estado Democrático de Direito, em trazer aquele indivíduo novamente para a legalidade em vida.

\section{ARMADILHAS DA OSTENSIVIDADE: a "pis- ta", a "rua" e o "administrativo"}

Antes de iniciar o trabalho de campo, sondando alguns policiais próximos sobre meu tema de pesquisa, surgiu a hipótese de que os evangélicos buscavam se envolver preferencialmente com atividades administrativas. Muito embora não existam estatísticas que corroborem essa afirmação, os policiais militares evangélicos com 
quem pude conversar foram unânimes em atestar as dificuldades encontradas pelos que professam sua fé em relação aos "serviços de rua". ${ }^{14}$

À medida que o trabalho de campo ganhava profundidade, a questão mostrou-se mais complexa, desdobrando aspectos bem mais sutis e interessantes. Uma primeira conclusão foi a de que os evangélicos não evitam o serviço de rua, mas evitam aquilo que chamam de "pista". Ao que parece, o emprego dessa categoria estabelece uma importante diferenciação nos tipos de serviços de rua. As atividades consideradas mais "pista" são também as mais problemáticas, no sentido de que podem expor o policial a situações de violência, conflito armado e risco de morte. Segundo os evangélicos entrevistados, essa vivência extremada da atividade policial tende a brutalizar os agentes, tornando-os cínicos, insensíveis, exaurindo-lhes progressivamente a capacidade de demonstrar empatia pelos dramas humanos e sociais com que se deparam.

Segundo meus interlocutores, muitos policiais evangélicos se afastam de algumas modalidades de policiamento "pista” para evitar esse processo de "embrutecimento", bem como a influência negativa de colegas com estilos menos ortodoxos de trabalho. São bastante emblemáticos os relatos de evangélicos que se "desviaram do caminho da santificação" à medida que foram se engajando em determinados tipos de policiamento, deixando se enredar pela "lógica da pista".

Quando eu entrei pra polícia, que eu saí do CEFAP [Centro de Formação e Aperfeiçoamento de Praças], eu fui trabalhar direto no trânsito, que é até uma atividade tranquila, é só aplicar o Código Nacional de Trânsito, você não cria inimizade, pelo contrário, você faz muita amizade com comerciante, com os moradores da localidade. Você faz até um serviço social mesmo, com a comunidade ali. Foi depois dessa ocorrência de assalto a

${ }^{14}$ A alternativa de "permanecer interno", envolvido com atividades administrativas, torna-se mais viável à medida que ascendem na cadeia hierárquica, tanto para o círculo das praças (soldados $\rightarrow$ cabos $\rightarrow$ sargentos $\rightarrow$ subtenentes), quanto para o de oficiais (tenente $\rightarrow$ capitão $\rightarrow$ major $\rightarrow$ tenente-coronel $\rightarrow$ coronel). Principalmente no caso dos soldados, a probabilidade de alocação no policiamento ostensivo é quase de $100 \%$, pois esse segmento hierárquico constitui a base do efetivo da PMERJ nas ruas. Existem, entretanto, estratégias alternativas, como a obtenção de um atestado de Incapacidade Física Parcial (IFP), por exemplo. banco que eu reagi no setor que eu trabalhava, que eu matei lá os dois marginais, me destaquei naquilo ali e o comandante me chamou pr'eu fazer outro tipo de serviço. Uma vez que também era perigoso eu ficar ali parado sozinho depois de ter participado de uma ocorrência desse tipo, né? Aî fui parar na RP [Rádio Patrulha], que a gente diz que é a escola da polícia, né, porque ali se atende todo o tipo de ocorrência possível. Ali eu comecei a conhecer o tráfico de drogas, invadir favelas, abordagem de saída de favelas, várias trocas de tiro, autos de resistência, ${ }^{15}$ depois de fazer alguns autos de resistência eu fui convidado pra trabalhar na Patamo [Patrulhamento Tático Móvel], por causa do meu desempenho, que eu era um cara que a gente diz 'operacional'. Ai quando você cai na Patamo já é o fim do mundo, você já está absolutamente desviado. Eu não tinha como ser evangélico. Apesar de eu estar desviado, eu sabia que aquilo ali que eu fazia estava errado, mas uma forca maior não permitia que eu voltasse para aquela minha origem inicial. Fui convidado pelo comandante para acompanhar ele para outro batalhão, o que eu fiquei muito orgulhoso, porque eu era da Patamo do comandante, que são os homens de confiança dele. Aí o trabalho da Patamo, foram mais autos de resistência, mais autos de resistência. O meu batalhão da época foi o primeiro a receber essa gratificação lá de 500 reais e eu fui o primeiro policial a receber esse prêmio de 500 reais. Naquele ponto, a Polícia Militar já tinha entrado no meu sangue (Ex-cabo, 33 anos de idade, 15 anos de polícia, nascido em lar evangélico. Entrevista realizada no Presídio Ary Franco).

A postura destemida presente no relato acima se tornou objeto de admiração de colegas e de avaliações positivas de supervisores, que passaram a recomendar o entrevistado para funções de grande prestígio para um policial com o perfil “operacional”. Além do reconhecimento de seus pares, o próprio governador do estado, representante mor da sociedade fluminense, concedeu-lhe um prêmio por seus "atos de bravura”. ${ }^{16}$ Este é um relato bastante difundido nos

${ }^{15} \mathrm{O}$ indivíduo que se opõe com violência ou ameaça o policial, ou ameaça a integridade física de terceiros, comete, em tese, o crime de resistência, previsto no artigo 329 do Código Penal: "Opor-se à execução de ato legal, mediante violência ou ameaça a funcionário competente para executálo ou a quem lhe esteja prestando auxílio”. Em seu artigo 292: "Se houver, ainda que por parte de terceiros, resistência à prisão em flagrante ou à determinada autoridade competente, o executor e as pessoas que o autorizarem poderão usar dos meios necessários para defender-se ou para vencer a resistência, do que tudo se lavrará auto, subscrito também por duas testemunhas". Em resumo, o auto de resistência é uma morte desencadeada pela ação policial, perpetrada em legítima defesa, ou na defesa de terceiros, frente à resistência violenta de seu opositor.

${ }^{16}$ Este tributo ficou popularmente conhecido como "premiação faroeste". Analisando os impactos para o período de vigência da premiação, instituída em 1995, Ignácio Cano (1997) atestou incrementos expressivos nos índices 
meios policiais, através do qual uma organização retrospectiva da experiência destaca uma relação inversa entre os parâmetros de "reconhecimento institucional" e a manutenção de padrões éticos de comportamento - no caso, fornecidos pela fé cristã-evangélica. À medida que "a polícia entra em seu sangue”, parece tornarse inviável para o entrevistado permanecer no "caminho da santificação".

Segundo as minhas observações, os serviços de rua considerados tranquilos para os evangélicos, tendem a ser também os mais solitários, não só os menos expostos à violência armada, por exemplo. O trabalho na "pista" tende a englobar atividades normalmente executadas por guarnições, em que o grupo precisa estar muito afinado em torno de uma determinada forma de trabalho. Quando um policial não se ajusta ao perfil de atuação da guarnição, ele tenta conseguir a sua transferência para outro grupo, com o qual guarda maior afinidade.

Quando o dissidente é um soldado ou um cabo - via de regra, um inferior hierárquico -, a tendência é que ele deixe o grupo e busque encontrar uma guarnição mais afinada com o seu perfil de trabalho. A estrutura de guarnição é típica do policiamento ostensivo regular, sendo formada por um número variável de praças em sua maioria, soldados - e comandada por um sargento. O que define a linha de atuação de uma guarnição são as orientações do sargento comandante. Se ele segue uma linha mais tradicional, de uma polícia mais dura, assim será a sua guarnição, pois o sargento é o responsável por selecionar os componentes do grupo. Se ele é evangélico, sua guarnição será selecionada en-

de letalidade das intervenções policiais para o município do Rio de Janeiro, onde o exame dos laudos de óbitos apresentavam indícios muito consistentes de execução sumária: perfurações de projétil de arma de fogo na cabeça, disparados pelas costas (indicando que o indivíduo não oferecia resistência armada, mas corria em direção oposta ao policial), perfurações múltiplas, à queima-roupa etc. Além do relatório de Ignácio Cano, ver também Verani (1996) "Assassinatos em nome da lei”. A Human Rights Watch (1997) produziu o relatório "Brutalidade Policial Urbana no Brasil", que também fornece um panorama bastante interessante sobre o aumento da letalidade das ações policiais, fomentada pela "premiação faroeste". tre aqueles policiais de sua unidade que com ele guardam afinidades doutrinárias e profissionais.

Os serviços mais problemáticos são aqueles que trabalham muito policial junto. Você manda na sua cabeça, mas não manda na dos outros. Agora, acontece também de o grupo não te querer ali. Já aconteceu comigo e o que eu fiz foi o seguinte: eu orei a Deus e pedi pros colegas pra sair, "Olha companheiros, eu vou pedir pra sair, porque eu sou cristão, não vou fazer as mesmas coisas que vocês, sou cristão”. Conversei com eles pra não ficar suspeita de que eu ia caguetar. Que passa a ser suspeito, né? Um policial evangélico numa guarnição convencional realmente vai trazer conflitos de interesses. Porque o policial evangélico não vai aceitar que haja desvio de condutas, que haja isso; principalmente se ele for superior aos outros. Se ele for um grau hierárquico inferior ele vai pedir pra sair ou até a guarnição não vai aceitá-lo. Agora, o verdadeiro evangélico não vai se corromper e se eu sou um sargento, comandante de Patamo e sou evangélico eu não vou me corromper e eu vou procurar botar pessoas que pensem igual a mim, porque se eu sou sargento e comandante da guarnição, eu boto quem está dentro da minha filosofia de pensamento. Hoje, na minha condição de antigo, se botarem um garoto desses na minha mão, ele vai ter que fazer o que eu quero, então a gente é que tem um dinamismo, uma liderança, é o elo entre o oficialato e a praça. Você consegue como graduado até conduzir quatro, seis homens... Mas, no serviço de rua, tu vai se indispor muito, tem muitas pessoas teimosas, entendeu? A dificuldade é ter uma guarnição pra me acompanhar na minha linha de raciocínio e fidelidade, não é isso? (Sargento evangélico, 39 anos de idade, 20 anos de polícia, 17 de conversão).

Na relação com o grupo, existe ainda mais um aspecto que afastaria o policial evangélico dos serviços de guarnição, principalmente quando seus colegas não seguem as mesmas orientações que ele: se um componente da guarnição erra, todos são punidos. Isso significa que, mesmo que o policial evangélico não compactue com os procedimentos equivocados adotados pelo grupo, ele ainda assim pode ser punido pelos equívocos cometidos por seus colegas.

Essa questão de problemas psicológicos, isso só quem pode responder é quem está na pista. Eu já trabalhei na pista, mas quando eu trabalhei, Deus me orientou e alguns colegas também me orientaram e eu acabei ficando interno. Com certeza, você faz parte de uma guarnição onde todo mundo é diferente daquilo que você escolheu como verdade absoluta, então, peraí, ali você é só mais um, e era motivo de eu ser escarnecido... Eu era soldado. Todo mundo escarnecia 'Meu irmão, não 
pode isso, não pode aquilo'. Como se eu não soubesse né? 'Não pode pegar isso não'. Eles faziam e 'Você não pode participar não, não sei o que...' Até aí eu levava na flauta, mas o convívio era ruim, porque numa guarnição você faz parte dela e se algo acontece ali está todo mundo enrolado, independente do que for, você não foi o ativo, mas vai junto. 'Você não tomou atitude nenhuma não?'. Era complicado. Uma guarnição toda evangélica seria mais fácil com certeza. Então, existe até comandantes que preferem, veladamente, colocar cristãos em certos lugares, pra ver se eles controlam os índices de corrupção. Na minha opinião, se for um cristão que ele colocar lá e for o mais antigo, se for o comandante, vai melhorar (Sargento evangélico, 37 anos de idade, 11 anos de polícia, 10 de conversão).

Independentemente do tipo de serviço de rua com o qual o policial se envolva, inevitavelmente ele tomará contato com toda sorte de inconsistências associadas ao lugar da polícia na organização do Estado: um lugar de fronteira, em que a estrutura estatal formal, igualitária, encontra o mundo das práticas sociais concretas, desiguais e hierárquicas. Na tentativa de equacionar os desajustes entre a letra da lei, as desigualdades sociais e as expectativas de eficiência em torno de seu trabalho, o policial está mais sujeito a cometer erros, desagradar alguém e ser punido. Os policiais militares conhecem bem as diversas armadilhas produzidas pelo funcionamento dessa estrutura esquizofrênica, e muitos deles - não só os evangélicos - procuram evitar seus desdobramentos, dando preferência aos serviços administrativos.

Por sua vez, tendo em vista tais dificuldades, os policiais militares que continuam no policiamento ostensivo podem reagir de diversas formas aos dilemas cotidianos do universo das ruas: alguns passam a demonstrar certa imobilidade, evitando tomar contato com as ocorrências; outros recorrem a métodos violentos ou ilegais para fazer movimentar o sistema (ou tirar vantagem dele), a despeito de suas lacunas e inconsistências.

\section{CONCLUSÃO}

A tipologia das formas profissionais e nãoprofissionais de respostas aos paradoxos do po- der coercitivo de Muir fornece alguns recursos teóricos interessantes para refletir sobre os esforços dos policiais evangélicos em conciliar os princípios morais de sua religião e o seu papel como agentes da violência do Estado.

Entre os evangélicos, a visão maniqueísta de bem e mal é inclusiva, englobando todas as figuras do universo policial - "cidadãos de bem", bandidos, prostitutas - em uma mesma compreensão trágica da natureza humana. Ninguém está livre do pecado, nem mesmo o próprio policial. Toda a criatura dotada de livre-arbítrio, segundo esta visão, está sujeita aos seus ardis, à sanha corruptora do demônio, que busca afastar as almas de Deus e lançá-las à eterna danação. "Nossa verdadeira luta não é contra a carne, nem contra o sangue, mas contra principados e potestades do mal", afirmam os evangélicos. Os antagonistas da autoridade policial são pessoas que fraquejaram frente às influências malignas.

Entretanto, quando a perspectiva trágica oferecida pela ideia de "batalha espiritual" não é acompanhada de uma moralidade integrada em relação à coerção, os policiais militares evangélicos podem relutar em exercer o poder coercitivo, mesmo quando apropriado e legalmente respaldado, caracterizando o perfil não-profissional que Muir chamou "reciprocator" ou "alternante" (Reiner 2004a, p.154). O tipo de respostas oferecidas pelos "alternantes" aos "paradoxos do poder coercitivo" se aproxima das estratégias dos policiais evangélicos que não lidam bem com a possibilidade de "privar uma 'alma desviada' da salvação", evitando modalidades de policiamento e áreas de atuação que os exponham a situações extremas de emprego da arma de fogo. Esse perfil pode até aceitar bem a possibilidade de desempenhar "serviços de rua", mas procura evitar os tipos de policiamento considerados "pista", de modo a se manter afastado de seus efeitos nocivos sobre a moralidade cristã.

Uma degeneração do tipo "alternante", segundo Muir, é a atitude característica do "avoider" ou "fujão" (Reiner, 2004a, p.154), um padrão não-profissional de respostas em que o 
policial nega terminantemente a possibilidade do exercício ético da coerção. Nesse tipo, enquadram-se as estratégias empregadas por policiais evangélicos que "se escondem em funções administrativas", pois veem como inviável uma existência que articule, simultaneamente, referenciais identitários policiais e evangélicos. Para este tipo, o abismo entre ser um homem bom e ser um bom praticante da coerção parece intransponível (Muir Jr, 1977, p.49).

Por fim, o perfil do policial que encontra unidade moral no ato da coerção por meio da desumanização do outro e da violação das regras é chamado por Muir de "enforcer" ou "sancionador" (Reiner, 2004a). Para realizar sua missão, ele desconsidera os constrangimentos e assimetrias de meios para responder aos "paradoxos do poder coercitivo", oferecendo respostas ilegais e ilegítimas aos que se rebelam contra a sua autoridade. Esse tipo de resposta não-profissional corresponde aos policiais que, ao se deixar enredar pela "lógica da pista", afastam-se dos padrões de vida cristã-evangélica, passando a ser considerados "evangélicos desviados".

Para Muir, o desenvolvimento de tipos de respostas profissionais e não-profissionais ocorre diariamente, a partir de técnicas que os policiais elaboram para defender-se frente aos "paradoxos da coerção". Essas decisões ativas se acumulam com o tempo e moldam seu modo de pensar, desenvolvendo padrões costumeiros de respostas. Um "bom policial" é aquele que busca oferecer respostas moralmente integradas para resolver o dilema de produzir fins justos por meio da força. Nesse tipo, enquadram-se os policiais evangélicos que articulam a outorga divida das autoridades e o recurso à legítima defesa, sintetizando, no discurso e na ação, o caráter atemporal das categorias cristãs e as realidades sempre emergentes da atividade policial.

Segundo Muir, três influências são cruciais no sentido de facilitar ou dificultar a consolidação de padrões de respostas profissionais, transformando inovações pessoais em compreensões gerais: o desenvolvimento e o cultivo da eloquência ${ }^{17}$; a relação com seus colegas (especialmente com seus supervisores); e a liderança de seu chefe ou comandante na consecução dos objetivos institucionais (1977, p.146).

Ao legitimar as respostas não-profissionais aos dilemas do exercício da autoridade e da coerção, a instituição policial oferece estímulos diametralmente opostos ao desenvolvimento dos atributos morais e intelectuais de um "bom policial". Ao contrário, omite-se da tarefa de construir uma sistemática organizacional de internalização de referenciais éticos, legais e profissionais adequados aos princípios de atuação das forças policiais em contextos democráticos.

Quando os policiais militares evangélicos reivindicam conexões entre a legítima defesa e a derivação divina da lei e da autoridade, buscam uma justificativa moral integrada para o exercício da coerção e os padrões de vida cristã. Informados pela ideia de "batalha espiritual", esses agentes adquirem uma compreensão trágica do mundo, das relações humanas e de seu papel na sociedade. Essa busca, entretanto, não é peculiar aos evangélicos. Todo policial, ao refletir sobre suas escolhas, tomadas na emergência do aqui e agora, busca algum nível de coerência entre seus princípios morais, as expectativas sociais e os referentes legais que constrangem a sua ação. O desenvolvimento de atitudes profissionais, segundo Muir, quando devidamente estimulado pela instituição policial, tende a neutralizar os efeitos corruptores do poder.

As instituições policiais precisam avançar em suas estratégias para irradiar padrões de respostas profissionais, influenciando o relacionamento entre as regras formais da lei e procedimentos e as regras subculturais, que são as diretrizes da conduta policial (Reiner, 2004b). A

${ }^{17} \mathrm{O}$ desenvolvimento da eloquência, outro fator levantado por Muir, não foi considerado neste artigo, pois envolveria toda uma discussão sobre as oportunidades disponibilizadas para os policiais elaborarem suas experiências (como no caso do atendimento pelo serviço de psicologia, por exemplo, muito criticado pelos policiais, para o qual a religião aparece como um meio alternativo) e a capacidade da instituição de incorporar e influenciar os aprendizados práticos transmitidos oralmente entre as gerações de policiais. 
experiência evangélica da atividade policial - e vice-versa - cria eventos friccionais em que categorias culturais são criativamente carregadas de novos significados, tornando simbólica e empiricamente possível a existência "policial militar evangélica”. Os esforços dos sujeitos para elaborar essas sínteses culturais, entretanto, expõem alguns focos de tensões e inconsistências, não só da busca evangélica por uma integralidade moral da coerção, mas de todo policial que tenta evitar seus poderes corruptores.

O lugar da religião no exercício da coerção, como espero ter conseguido demonstrar, diz muito sobre a sutil fronteira entre o arbítrio e a arbitrariedade policial, nem sempre negociados em termos formalmente reconhecidos. Sua batalha diária contra o pecado traduz, em termos atemporais, o dilema de produzir respostas policiais eficientes sem, entretanto, sucumbir aos efeitos corruptores do poder - que, no que podemos chamar de "cultura cristã-evangélica policial”, é representado pelos ardis do demônio. Em razão do caráter cumulativo das decisões policiais concretas na conformação das diversas "subculturas policiais” (Muir Jr, 1977; Reiner, 2004b), quanto menos institucionalizados os parâmetros de atuação profissional, mais difusos e obscuros se tornam os processos de tomada de decisão policial. Impossibilitada de influenciar ativamente as condutas concretas, a instituição policial acaba por ocultar a existência de mecanismos subculturais perversos e preconceituosos de construção da suspeita e de inscrição de indivíduos, grupos e territórios em seu campo de vigilância.

(Recebido em agosto 2010) (Aceito em outubro 2010)

\section{REFERÊNCIAS}

A BÍBLIA SAGRADA. Trad. João Almeida corrigida e revisada. São Paulo: Editora Fiel. 1994

ALBERNAZ, Elizabete R Deus e o Diabo na Terra do Sol: visões de espaço público, moral religiosa e ética profissional entre policiais militares evangélicos do Rio de Janeiro. 2009. 221 f. Dissertação (Mestrado em Antropologia Social) - Programa de Pós-Graduac̃ão em Antropologia Social da Universidade Federal do Rio de Janeiro, Museu Nacional. Rio de Janeiro: PPGAS/UFRJ/MN, 2009.

BITTNER, Egon. Aspectos do Trabalho Policial. São Paulo: EDUSP, 2003

CANO, Ignácio. Letalidade da ação policial no Rio de Janeiro. Rio de Janeiro: ISER, 1997

ELIAS, Norbert. O processo civilizador. Rio de Janeiro: Jorge Zahar Ed., 1994. v.1.

MARIZ, Cecília. A teologia da batalha espiritual: uma revisão da bibliografia. Revista Brasileira de Informação Bibliográfica em Ciências Sociais (BIB),São Paulo, v.47, n.1, p.3348,1999 .

MUIR JR., K.W. Police: streetcorner politicians. Chicago: Chicago University Press, 1977.

MUNIZ, Jaqueline. A crise de identidade das polícias militares brasileiras: dilemas e paradoxos da formação educacional. Security and Defense Studies Review: Center for Hemisphrtic Studes. Washington, DC, v.1 mayo, p.22-25, 2001.

; PROENÇA JR., D.; DINIZ, E. Uso da força e ostensividade na ação policial. Conjuntura Política: boletim de análise, Belo Horizonte, UFMG, n.6, p.22-26, 1999.

REINER, Robert. A cultura policial. In: REINER, Robert. A política da polícia. São Paulo: Ed. USP, 2004a. p.131-160.

Os poderes da polícia e a responsabilização. In: p. $239-280$.

SANCHIS, Pierre. O repto pentecostal a cultura católica brasileira. In: ANTONIAZZI, A. (Ed.) Nem anjos nem demônios: interpretações sociológicas do pentecostalismo. Petrópolis: Vozes, 1994. p.34-63.

SENTO-SÉ, João Trajano. Criminalidade, violência e imagens do Rio de Janeiro. In: BIRMAN, Patrícia; NOVAES, Regina; CRESPO, Samira (Org.). O mal à brasileira. Rio de Janeiro: EdUERJ, 1997. p.135-146.

SYKES, Gresham M'Gready; MATZA, David. Técnicas de neutralización: uma teoria de la delincuencia. Caderno $C R H$ : revista do Centro de Recursos Humanos da UFBA, Salvador, v.21, n.52, jan./abr., p.163-170, 2008.

VALLADARES, Licia. Os dez mandamentos da observação participante. Revista Brasileira de Ciências Sociais, São Paulo, v.22, n.63, p.153-155, 2007.

VERANI, Sérgio. Assassinatos em nome da lei. Rio de Janeiro: Ed Aldebarã, 1996.

WEBER, Max. Ciência e política: duas vocações. São Paulo: Ed.Cultrix, 2000

ZALUAR, Alba. O crime e a não-cidadania: os males do Brasil. In: BIRMAN, Patrícia; NOVAES, Regina; CRESPO, Samira (Org.) O mal à brasileira. Rio de Janeiro: EdUERJ, 1997. p.109-134. 
AT THE BORDER BETWEEN GOOD AND

EVIL: views of professional ethics and religious morality among evangelical military police in Rio

\section{Elizabete R Albernaz}

This paper examines some paradoxes experienced by evangelical military police actions - active members of congregations located in the barracks of the State of Rio de Janeiro Military Police (in Portuguese, PMERJ), in the search for dialogue between their faith, the prerogatives of their mission and the values that inform the dominant police practice. The study is based on the concept of "techniques of neutralization" of (Sykes and Matza, 1996) as well as the typology of Muir Jr. (1977) on police responses of the socalled "paradoxes of coercion". The analysis shows that the Manicheist rhetoric of "spiritual warfare" is transposed to the police environment and vigorously appropriated to the experience of coercion in police practices. This result seems to show the construction of evangelical ethical standards for police action, in which daily conflicts are conducted as visible expressions of the nefarious influence of the demon, responsible for crime, debauchery and all sorts of socially disapproved behaviors.

KEYWORDS: military police, police culture, evangelical churches, spiritual warfare, police discretion.
À LA FRONTIÈRE DU BIEN ET DU MAL: perceptions de l'éthique professionnelle et morale religieuse des policiers militaires évangéliques cariocas

\section{Elizabete R Albernaz}

Cet article analyse le paradoxe conflictuel de l'action des policiers militaires évangéliques membres actifs de congrégations existantes, au sein des bataillons de la Police Militaire de l'État de Rio de Janeiro (PMERJ), à la recherche d'un dialogue entre leur foi, les prérogatives de leur mission et les valeurs de la pratique policière dominante. Létude est basée sur les "techniques de neutralisation” (Sykes et Matza, 1996) ainsi que sur la typologie de Muir Jr. (1977) concernant les réponses de la police appelées "paradoxes de la coercition.” Lanalyse montre que la rhétorique manichéenne de la "guerre spirituelle" est transposée au sein de la police militaire et appropriée vigoureusement à l'expérience des pratiques policières coercitives. Ce résultat semble montrer l'élaboration de normes éthiques évangéliques pour l'action policière, où les conflits de tous les jours sont considérés comme des expressions visibles de l'influence néfaste du démon, responsable du crime, de la débauche et de toutes sortes de comportements socialement désapprouvés.

MOTS-CLÉs: police militaire, culture policière, évangéliques, combat spirituel, pouvoir discrétionnaire de la police.

Elizabete Ribeiro Albernaz - Mestre em Antropologia Social pela Universidade Federal do Rio de Janeiro, Programa de Pós-Graduação em Antropologia Social do Museu Nacional. Assessora Técnica de Gabinete da Secretaria de Estado dos Negócios da Segurança Pública de São Paulo. Principais publicações: ALBERNAZ, Elizabete; CALDEIRINHA, Daniela. Mídia e Segurança Pública: um balanço. In.: Mídia e Segurança Pública. Cadernos Temáticos da Conseg, ${ }^{\circ}$ 1, Ano 01, 2009. Ministério da Justiça. Brasília-DF. 52p.; ALBERNAZ, Elizabete; SUTTON, Heather. Controle de armas e munições: um desafio para a segurança pública do Brasil. In.: Controle de Armas e Munições. Cadernos Temáticos da Conseg, $\mathrm{n}^{\circ}$ 2, Ano 01, 2009. Ministério da Justiça. Brasília-DF. 48p.; ALBERNAZ, Elizabete. Uso progressivo da força: dilemas e desafios. In: Cadernos Temáticos da Conseg, $n^{\circ}$ 5, Ano 01, 2009. Ministério da Justiça. Brasília-DF. 64p. 